\title{
A century of science and service
}

Rose Hayden-Smith, UC Cooperative Extension 4-H Youth, Family and Community Development Advisor, Ventura County

Rachel Surls, UC Cooperative Extension Sustainable Food Systems Advisor, Los Angeles County

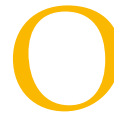
n a warm Friday, May 8, 1914, in Washington D.C., two pieces of new legislation awaited President Woodrow Wilson's signature: a proclamation establishing the second Sunday each May as Mother's Day, and the Smith-Lever Act. The honoring of mothers dominated the news that day, but Wilson recognized the importance of the SmithLever Act, calling it "one of the most significant and far-reaching measures for the education of adults ever adopted by government."

Sponsored by Sen. Hoke K. Smith and Rep. Asbury F. Lever, the bill was the result of national efforts to create a new educational model for U.S. agriculture. At that time, land-grant universities ran farmers institutes and short courses taught by lecturers, and the U.S. Department of Agriculture (USDA) offered its own form of Extension work that focused on pest control field demonstrations in the South and farm management in the North. Yet there was no consistent or efficient way to deliver important knowledge from the university campuses to the communities that needed it. Passage of Smith-Lever launched a century of innovation in U.S. education that continues to this day. In California, the educational model born out of the legislation is UC Cooperative Extension. For 100 years this statewide network of UC researchers and educators has developed and provided science-based information to solve locally relevant challenges in the areas of economics, agriculture, natural resources, youth development and nutrition.

\section{Progressive roots}

Agriculture has always been vital to America. In 1860 , at the outset of the Civil War, farmers made up $58 \%$ of the U.S. labor force. It was that demographic that created the impetus behind the 1862 Morrill Act, which gave each state a grant of land to establish a college that would teach practical subjects such as agriculture and engineering (see California Agriculture, April-June 2012, pg. 42). A key role of those

Continued on page 10

\section{California milestones}

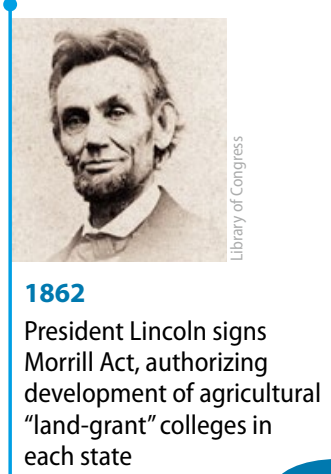

1880

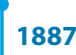

Hatch Act establishes federal funding for agricultural research in state land-grant colleges
1868

University of California founded to teach "agriculture, mining and the mechanical arts"

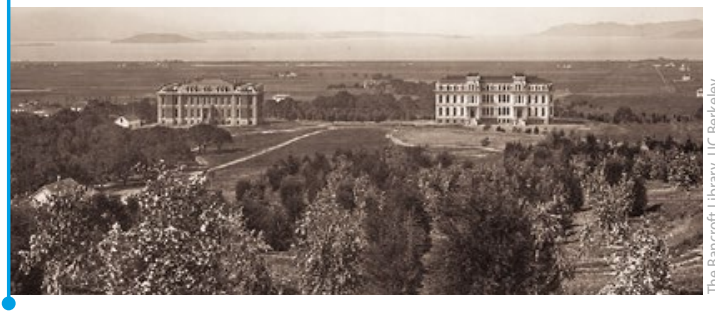

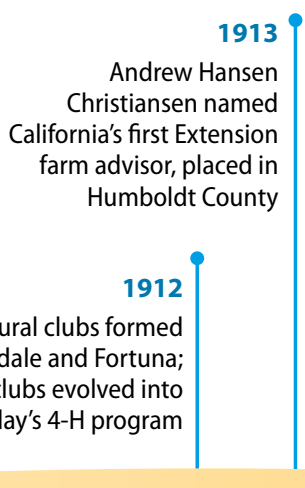

1900

\section{in Ferndale and Fortuna;} these early clubs evolved into today's 4-H program

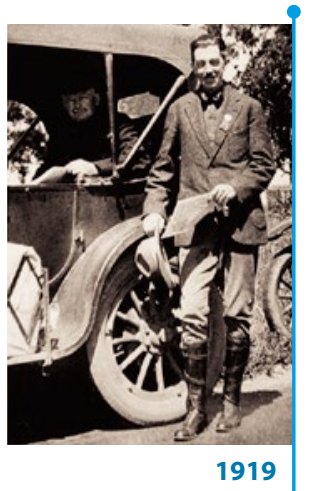

B.H. Crocheron recruited to direct state's Agricultural Extension Service, which he does for next 35 years

1918

First UC Extension specialist, a poultryman, hired with goal to double egg production from 80 eggs per hen per year average 


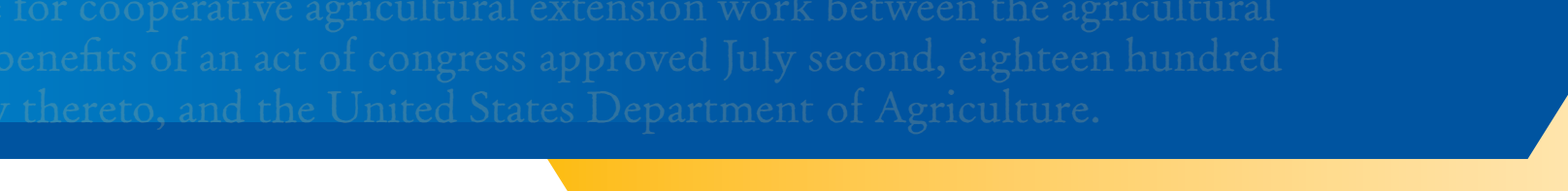

\section{The presidential roots of Cooperative Extension}

$\mathrm{O}$ ver the course of more than half a century, Presidents Abraham Lincoln and Woodrow Wilson signed bookend legislation that created the land-grant institutions and Cooperative Extension. Despite very different backgrounds and political ideologies, they reached very similar conclusions about the vital nature of agricultural education to U.S. prosperity.

President Lincoln, a Republican, who signed into law the Morrill Act, creating the nation's system of public higher education and land-grant institutions, and President Wilson, who signed the SmithLever Act, which created the Cooperative Extension service, were

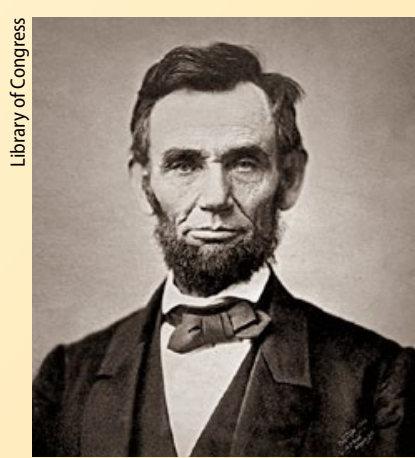

President Abraham Lincoln both shaped by the American Civil War. Lincoln experienced the war firsthand, serving as president of the United States when the South seceded from the Union, and brought the nation intact, although battered, through 4 grueling years of war. Lincoln was born and raised on a farm, and his lack of formal education influenced his ideas about educational access for Americans. Life on the farm also influenced his ideas about the importance of creating a federal-level agency (the USDA, what Lincoln termed "the people's department") to manage agriculture, of opening up land to settlers by means of the Homestead Act, and of creating a transnational railroad system to promote commerce.

A Democrat, Wilson was born in Virginia. At the end of the Civil War, when he was only 8 years old, he watched the former Confederate president, Jefferson Davis, brought through his community in chains. As a youth he saw how local farmers struggled after the war. He attended elite educational institutions, including the University of Virginia and the College of New Jersey (later renamed Princeton University), and received a doctorate from Johns Hopkins University. Wilson was the first president to ride to his inauguration in an automobile. He never forgot his firsthand observations of the economic challenges Southern farmers faced in the post-Civil War era; these experiences strongly influenced his ideas about scientific agriculture and the importance of Extension education.

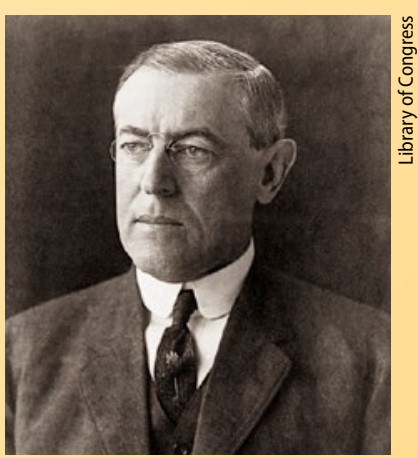

President Woodrow Wilson

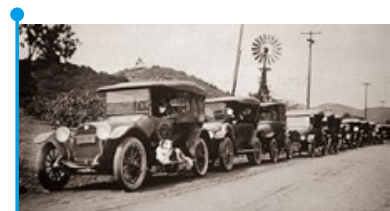

1920

Crocheron establishes week-long traveling conferences where caravans of farm advisors and Farm Bureau representatives travel for hundreds of miles viewing selected farms.

Farm Bureau centers established in more than 500 rural communities

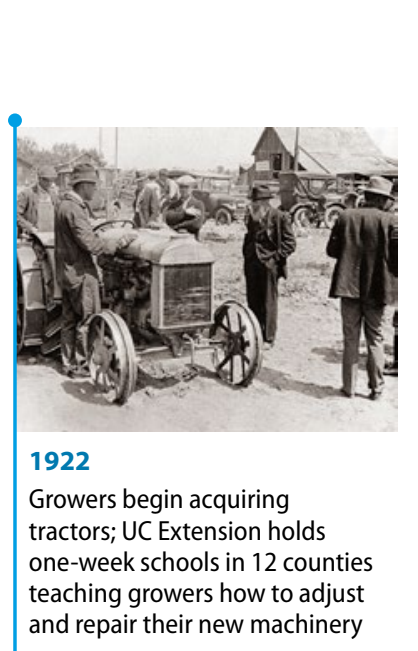

1924

Extension workers help bring an outbreak of foot and mouth disease under control

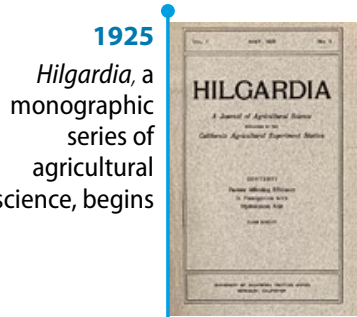

Extension academics begin specializing in poultry, dairy, citrus, walnuts, agricultural engineering, etc.

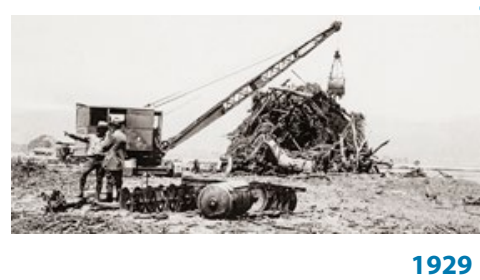

Extension provides emergency assistance when St. Francis Dam break inundates portions of Ventura and Los Angeles counties

Extension Director Crocheron embarks on fact-finding tour in Asia to investigate potential markets for California specialty crops; his outlook is not optimistic

\section{1}

Volunteer leader concept implemented for high school boys' and girls' agricultural clubs organized by farm advisors, forming the basic structure and philosophy for today's 4-H Youth Development Program

\section{3}

Extension completes first decade with 40 farm advisors, 33 assistant farm advisors and 21 home demonstration agents in county offices

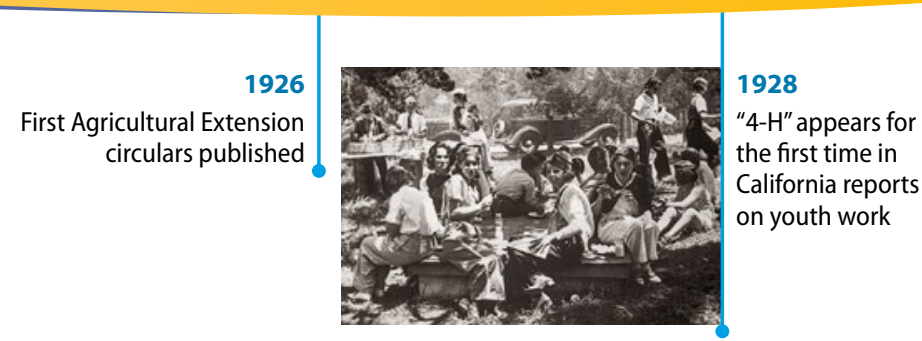


colleges was to develop knowledge that would help farmers produce enough food and fiber to meet the needs of a growing nation.

In 1887, the Hatch Act was passed to further this mission; it provided land-grant colleges with funds to develop agricultural experiment stations, where research was conducted. Passage of the Adams Act in 1906 doubled funding to the research stations, while requiring a new funding commitment from state sources. The infusion of federal and state capital facilitated agricultural research, education and innovation, and generated increasing interest in U.S. agriculture among policymakers concerned about food security and increasing economic opportunities.

Five years of debate had preceded the Smith-Lever legislation. The McLaughlin Bill, proposed in 1909, left no clear role in Extension work for the USDA. Opponents of that bill were familiar with the work of early Extension educator Seaman A. Knapp and argued for his model, which emphasized demonstration work on farms. The final Smith-Lever legislation was a compromise, facilitated by USDA Secretary David Houston, that proposed a single Extension service from the USDA's agricultural
Extension system and land-grant education, and created a federal, state and county funding formula for it that persists to this day.

The intent of the Smith-Lever Act, like earlier agricultural legislation, was broadly democratizing. Initially, Extension focused on improving and reforming rural life, partly in response to the findings of the Country Life Commission, created by President Theodore Roosevelt in 1908. The Smith-Lever Act was rooted in the Progressive philosophy of helping people help themselves, a philosophy that continues to inform Cooperative Extension's work today, and it demonstrated Progressive Era beliefs in the value of public-private partnerships and shared funding models.

In the case of Cooperative Extension, the model included federal (USDA), state (land-grant universities) and local support (county funding, and the organization of a local Farm Bureau to sponsor the work). This relationship with the Farm Bureau was a vital component in Cooperative Extension's formation and identity; their growth and partnership has been Continued on page 12

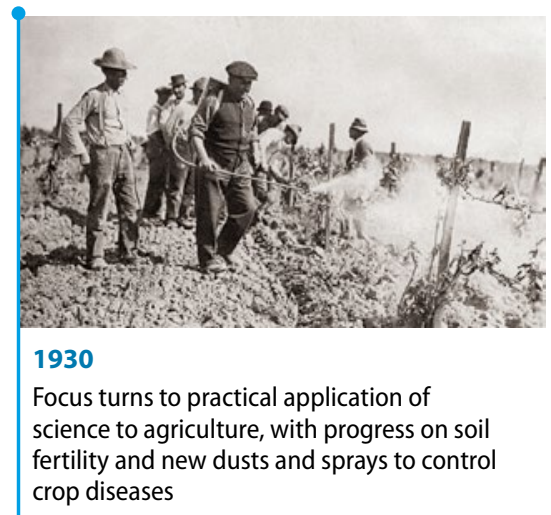

1934

Extension tapped to help federal government implement and administer Agricultural Adjustment Administration programs to help growers stabilize their incomes

\section{4}

Severe drought hits California: 18 California counties declared emergency areas eligible for federal funds; farm advisors serve as government agents in purchasing livestock in the hardest-hit areas

1938

Federal-state agreements establish pilot land-use planning program in U.S. counties; UC Extension monitors programs in Riverside, Kern, Sonoma and Yuba counties

$$
1937
$$

George B. Alcorn joins Extension as agricultural economist; he will become third director of California Agricultural Extension Service in 1956

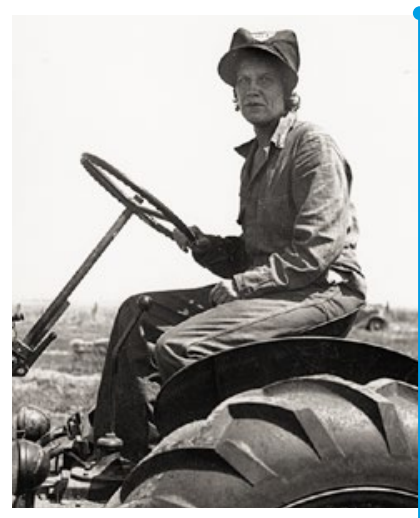

1943

Extension asked to administer Emergency Farm Labor Project to assure adequate supply of workers for wartime agricultural production

1942

In response to Pearl Harbor, Extension agents organize Emergency Farm Fire Protection

Project, forming more than 2,000 volunteer fire companies in 42 counties to thwart possible incendiary attacks

Director Crocheron organizes California Minute

Men rural militia; 20,000 men sign up through county Extension offices to serve on reserve duty

\section{0}

1932

"Cal-Approved" seed program begins to ensure quality seed for standard and improved varieties

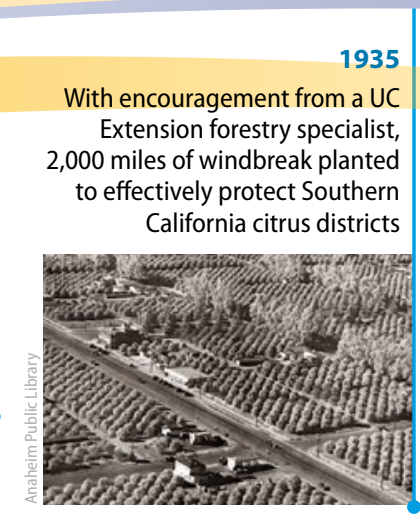

\section{6}

Congress approves Soil Conservation and Domestic Allotment Act to conserve soil and prevent erosion; Extension agents given responsibility of carrying out organizing work

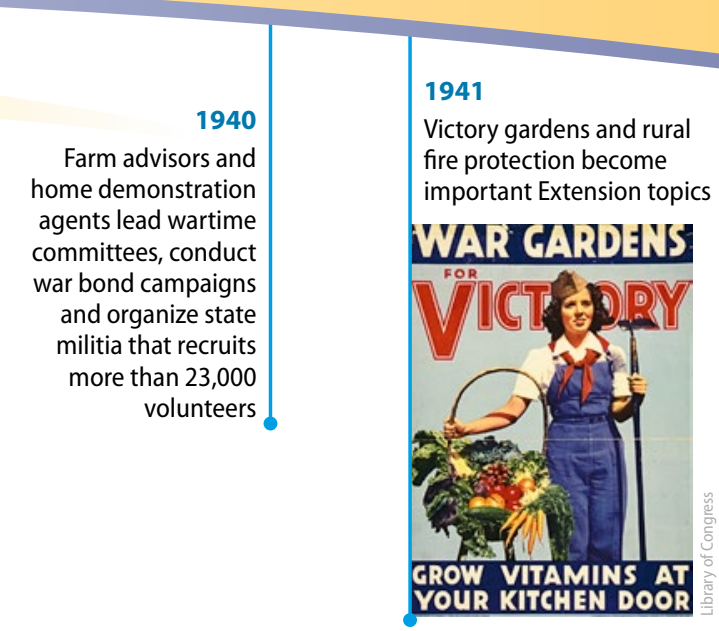




\section{A profile in excellence}

Tn the late 1930s and early 1940s, a young UC-trained agronomist named Milton D. Miller worked as an assistant farm advisor in the UC Cooperative Extension office in Ventura County. When the United States entered World War II, Miller enlisted in the U.S. Army as a captain and was deployed to the Pacific theatre. He worked for the U.S. Subsistence Procurement Branch in Australia, where he helped farmers transition from hand-hoeing vegetable fields to using mechanical weeders, as part of the effort to boost Allied wartime food production. An engaging writer, Miller corresponded regularly with the Cooperative Extension staff in Ventura, exchanging news and thanking them for gift packages that included fruitcake, handkerchiefs and tobacco.

After the war ended, Miller returned to service with UC Cooperative Extension, working as an Extension specialist from what eventually became the UC Davis campus. His notable career spanned more than 50 years, and his work in rice, cereal and oilseed crops, and food procurement had local, state, national and international impacts. Producers here and all over the world benefited from his research on rapidly developing technologies to improve practices and increase production.

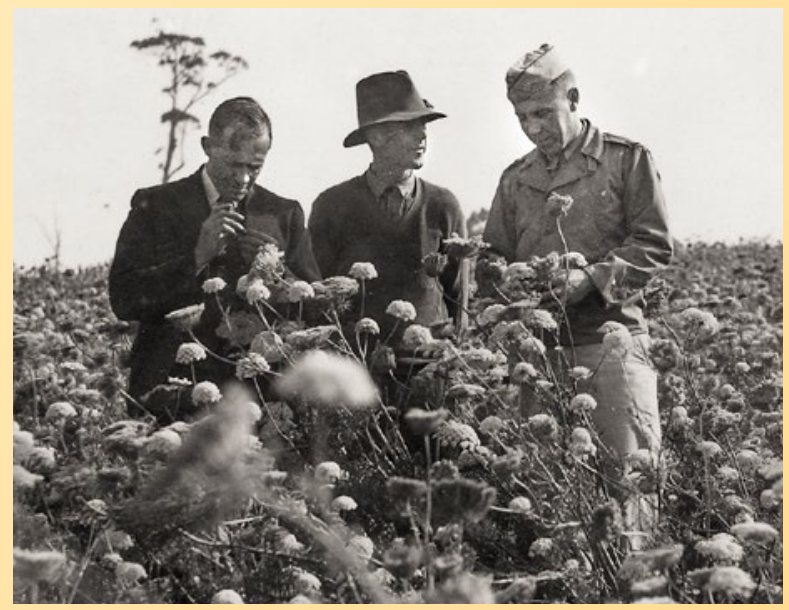

Milton Miller (right) in a Tasmanian carrot seed production field during World War II, 1944.

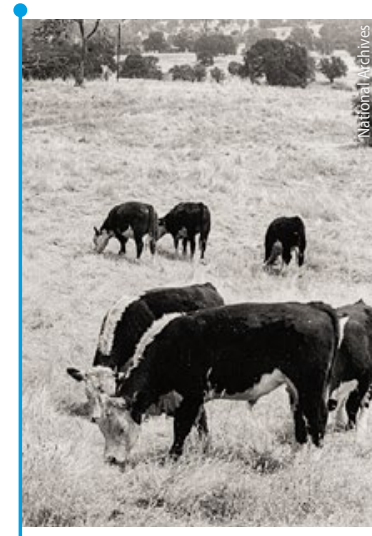

1945

In response to newly formed Forest Service grazing restrictions, Extension advisors help ranchers determine most efficient locations and methods to feed cattle
1948

Extension Director Crocheron dies suddenly, ending an era; acting director Chester Rubel writes "... a deep understanding of rural problems, a genius for organization, and a devotion to agriculture and to rural people ... made [Crocheron] an outstanding leader.... The foundations which he laid are sound and enduring ... His work will go on."

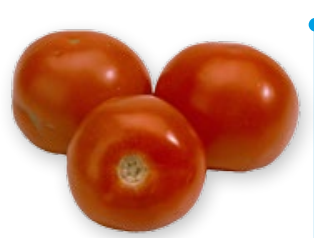

1950

Extension reorganizes to better cope with scientific and technical advances and with California's rapidly increasing population; home demonstration agents become home advisors; county director positions created to coordinate local farm and home advisor programs

New specialist positions added in range management, ornamental horticulture, subtropical horticulture, plant pathology, vegetable crops, deciduous fruits and nuts, agricultural engineering, marketing, extension education, 4- $\mathrm{H}$, home economics, youth counseling, apiculture, biometrics, climatology, crops processing, forest products, nematology, parasitology, enology, pesticide safety, consumer marketing, wildlife management, public affairs, radio-TV, dairy products and soil and water salinity

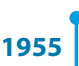

Extension staff totals 549 , more than double 1940's Extension workers
1956

UC Davis scientists and Extension farm advisors develop tomato varieties around state, identifying three new hybrids with superior yields

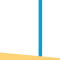

(n)

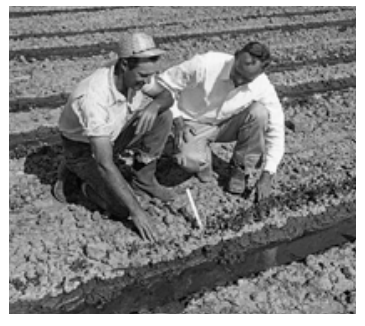

1957

Extension farm advisors work on improving irrigation efficiency by applying water based on specific soils and crop needs

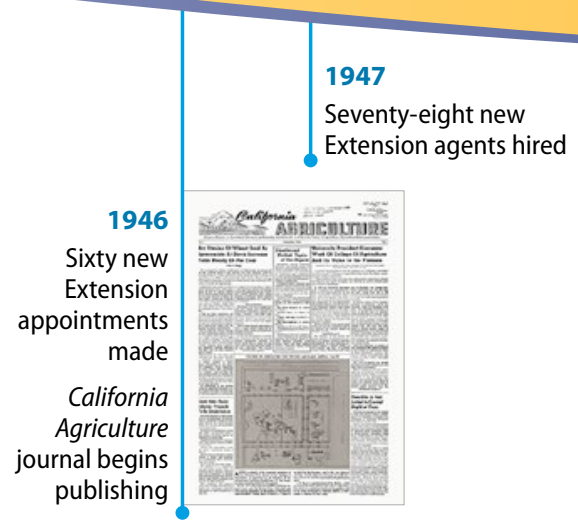

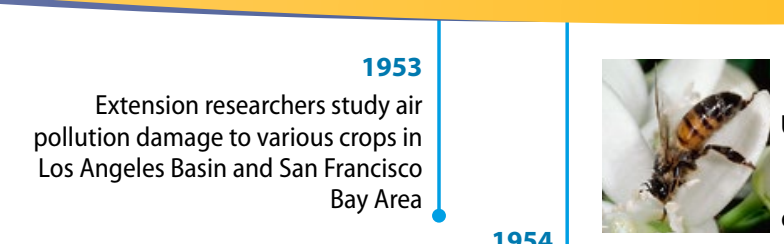

1954

UC Extension specialists coordinate with USDA to develop new shade structures for livestock in hot weather 
extraordinarily successful in advancing American agriculture. Local farmers and Cooperative Extension shared ownership in this shared model and the knowledge produced, and they still do.

What is difficult to comprehend today, 100 years later, is the sense of urgency surrounding the need to improve U.S. agriculture in 1914. The nation's agricultural sector faced

Passage of Smith-Lever launched a century of innovation in U.S. education. In California, the educational model born out of the legislation is UC Cooperative Extension. difficulties in a number of areas, including production, yield, labor sources and distribution. Rural areas were depopulating, and the number of farmers was dropping. At the same time, an inexpensive, secure and ordered food supply was believed essential for civil order and national progress.

1914 was a momentous year. The Panama Canal opened. Ford Motor Company established an 8-hour workday and increased wages. The National Guard fired upon striking miners in Colorado. Racial tensions ran high, as did tensions between rural and urban

populations. U.S. naval forces landed and occupied Veracruz, Mexico, bringing the two countries to the brink of war. By August, World War I had started, and U.S. agricultural products were sorely needed to feed and support our allies. Efficient agriculture backed by scientific solutions became a national priority.

\section{Partners in California}

Even before passage of the Smith-Lever Act in 1914, efforts were already under way to create an agricultural Extension system in California, building on the success of the state's land-grant college, the University of California. The first UC campus, at Berkeley, had agriculture as an important early focus. In 1907, a university research farm was opened in Davisville to serve Berkeley students. That site grew into a new campus, UC Davis. The same year, UC established the Citrus Experiment Station in Riverside, which was instrumental in helping California emerge as the nation's premier citrus producer, creating a second Gold Rush of sorts, as thousands flocked to the Golden State to capitalize on the opportunities that the state's agricultural and natural resource abundance

Continued on page 14

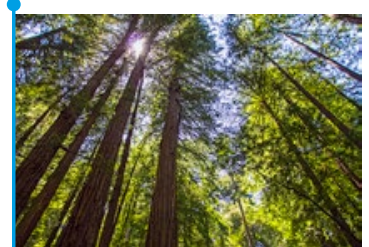

1962

Experiment Station researchers and specialists study how to protect state's redwood trees from soil compaction and other damage from recreation, logging and development Consumer Sciences 4-H programs developed in urban, low-income areas

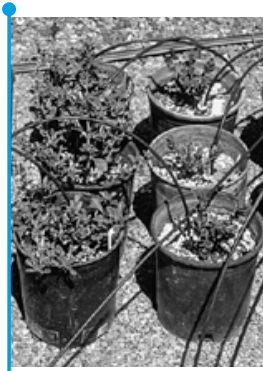

1965

Extension irrigation specialist and Sacramento County farm advisor encourage nurseries to use plastic tubes with electric timer to irrigate containers, rather than overhead sprinklers 50th anniversary of Smith-Lever Act; UC Extension has 532 farm and home advisors and specialists in 50 subject areas

\section{Extension programs begin to take an international perspective, reflecting concerns about world food supply \\ Programs established in community development, farm personnel management, integrated pest management \\ (IPM) and marine fisheries}

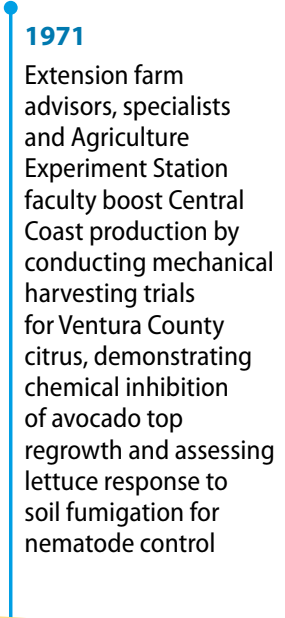

1971

Extension farm aculty boost Centra conducting mechanical 1967 Extension farm advisors work with UCD's Department of Vegetable Crops to develop new varieties of peppers resistant to tobacco mosaic virus

\section{3}

Farm advisors work with rice growers in Butte, Colusa, Glenn, San Joaquin, Sacramento, Sutter, Yolo and Yuba counties on fertilizer efficiency biocontrol efforts well under way; scientists release imported parasitic wasps to combat specific citrus pests
Extension entomologists and Fresno County farm advisors study impact of insecticides on beneficial insects in cotton fields, part of UC's work on pest control methods that utilize beneficial insects, mites and spiders

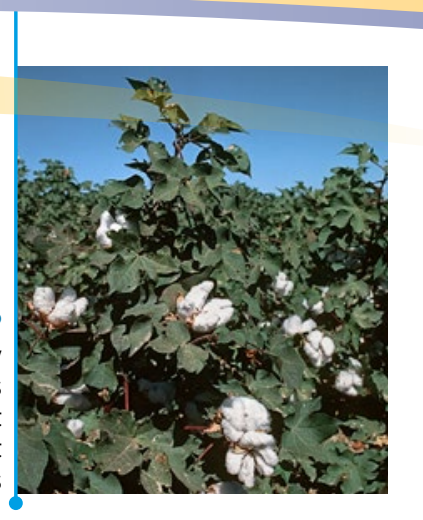

1969

Expanded Food and Nutrition

Education Program (EFNEP) developed to reach lowincome families

1972

UC conducts drip irrigation experiments on San Diego County avocados

In response to environmental concerns, UC works with Santa Clara County's canning industry on using cannery wastes as soil amendment 


\section{May 8, 2014: Day of citizen science}

$\mathrm{T}$ he real strength of UC Cooperative Extension is its ability to facilitate and build networks of knowledge that include scientists, producers, community members and practitioners. We learn together. This engaging process by everyone, not just the professional experts, has been an important part of our national history. Before the formalization of higher education and the specialization of scientific disciplines, much of our scientific knowledge was gathered by citizens through trial and error and then passed along to others. Presidents George Washington and Thomas Jefferson shared their knowledge of agricultural science in their correspondence and at agricultural fairs and meetings. Benjamin Franklin published scientific discoveries that provided a foundation for future technological innovation. John Bartram, a self-trained botanist and explorer, presented his plant knowledge in Philadelphia by making a garden, considered by many to be the nation's first significant botanical collection.

Citizen science is gaining traction in contemporary communities. Also known as crowd science, crowd-sourced science, networked science or public participation in science research, citizen science is a form of participatory scientific research conducted, in whole or in part, by amateur or nonprofessional scientists. Through citizen science projects, community members engage and participate in scientific research by contributing their own knowledge, observations and intellectual efforts, often using social, web-based technologies or mobile applications.

On Thursday, May 8, 2014, the Division of Agriculture and Natural Resources (UC ANR) will celebrate the 100th birthday of UC Cooperative Extension with a citizen science event - the Day of Science and Service. UC Cooperative Extension will crowd-source data for citizen science projects about water, food and pollinators. Every Californian is invited to participate in this free celebration of science.

UC ANR is developing data collection maps, and participants will be able to access them through their computers or smartphones and add their data directly to the maps. After adding data, they will be taken to a landing page with more information about why the questions are important and links to additional research in these three areas. After the Day of Science and Service, the data will be tabulated and analyzed, and the results will be shared with participants.

For more information about participating, visit http://Beascientist.ucanr.edu.

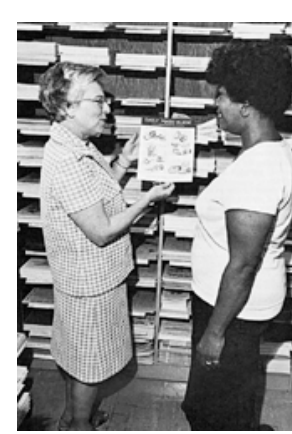

1976

UC research indicates that EFNEP improves dietary practices of low-income populations

\section{7}

UC Small Farm Program established to focus on specialized needs of small-scale and limitedresource growers

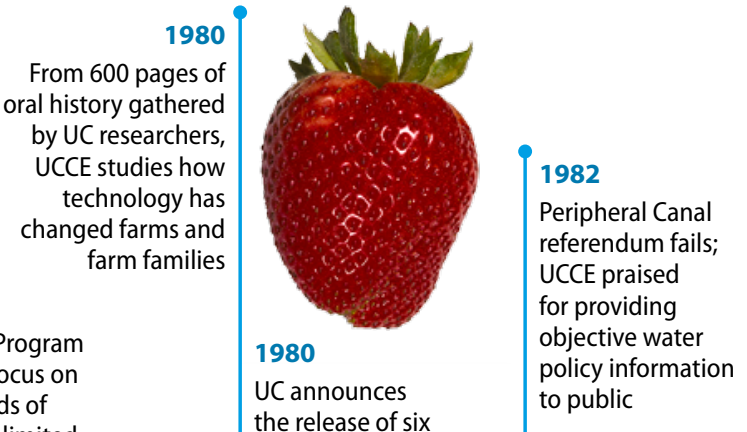

$$
\begin{array}{r}
1986 \\
\text { UC begins two } \\
\text { environmentally oriented } \\
\text { programs: Sustainable } \\
\text { Agriculture Research and } \\
\text { Education Program, to help } \\
\text { California growers practice } \\
\text { sustainable production } \\
\text { and marketing systems; } \\
\text { and Integrated Hardwood } \\
\text { Range Management } \\
\text { Program, to study } \\
\text { problems facing oak trees } \\
\text { and other hardwoods }
\end{array}
$$

1974

UC changes name of Agriculture Extension Service to UC Cooperative Extension (UCCE) to reflect its broadening social and economic purview

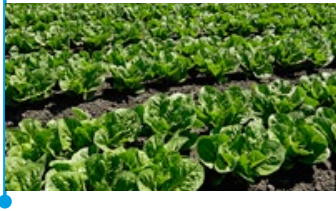

UC explores impacts of significant air pollution on Southern California leafy vegetables and on San Joaquin Valley cotton production

\section{9}

UC Statewide Integrated Pest Management Program formed to accelerate research and education on production alternatives that use fewer chemicals
1981

UC survey of agricultural college graduates shows women have not yet broken barriers in employment, salaries and status in agriculture

UC hires its first affirmative action officer to encourage more women and minorities to seek careers in $\mathrm{CE}$

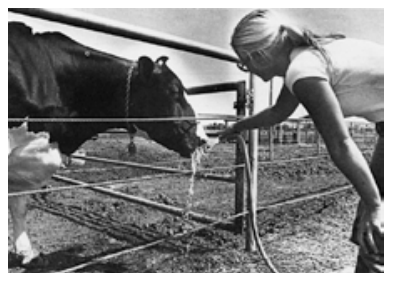


seemed to ensure. The experiment station at Riverside served as the foundation for the UC Riverside campus.

By the time the Smith-Lever Act became law, new knowledge and technologies developed by UC scientists were critical to the growth of farming and allied industries around the state. UC agriculture faculty were already offering short courses at farmers institutes, but farmers were clamoring for more and eager to have a Cooperative Extension educator, known as a farm advisor, assigned to their community.

Anticipating passage of Smith-Lever, UC officials required each county government that wanted to participate in a Cooperative Extension partnership to allocate funding to help support Extension work in that community. Additionally, it was required that a group of farmers in participating counties organize into a Farm Bureau to help guide the Cooperative Extension farm advisor on the issues of local agriculture. (These grassroots groups later evolved into the California Farm Bureau Federation.) The first California county to sign up, Humboldt County, had its farm advisor in place by July 1913, before passage of the federal legislation. Seven more counties came on board in 1914, and in the following years 41 of the 58 California counties secured Cooperative Extension farm advisors.
Cooperative Extension played a critical role on California's home front during World War I, helping farmers to grow enough wheat and other crops to meet expanded wartime needs. Extension's value was quickly established as farmers came to rely on having an expert close at hand who was familiar with local conditions and crops. In addition to addressing the needs of farmers, Cooperative Extension soon expanded to provide educational opportunities for their families. Female extension agents — home advisors - were hired; they taught food preservation and nutrition and ran other programs for rural women and activities for local youth. This new generation of college-educated female home economists increased the contact and interchange between urban and rural communities, especially on social and domestic issues. Cooperative Extension also reached thousands of young people who would learn about food production, animal husbandry, cooking, science and more through participation in 4-H clubs.

\section{UC Cooperative Extension today}

UC Cooperative Extension, part of UC Division of Agriculture and Natural Resources (UC ANR), is comprised today of 320 locally based Cooperative Extension advisors, 650 campusbased Cooperative Extension specialists, 1988

UCCE reorganized, making campus-based specialists integral part of academic departments
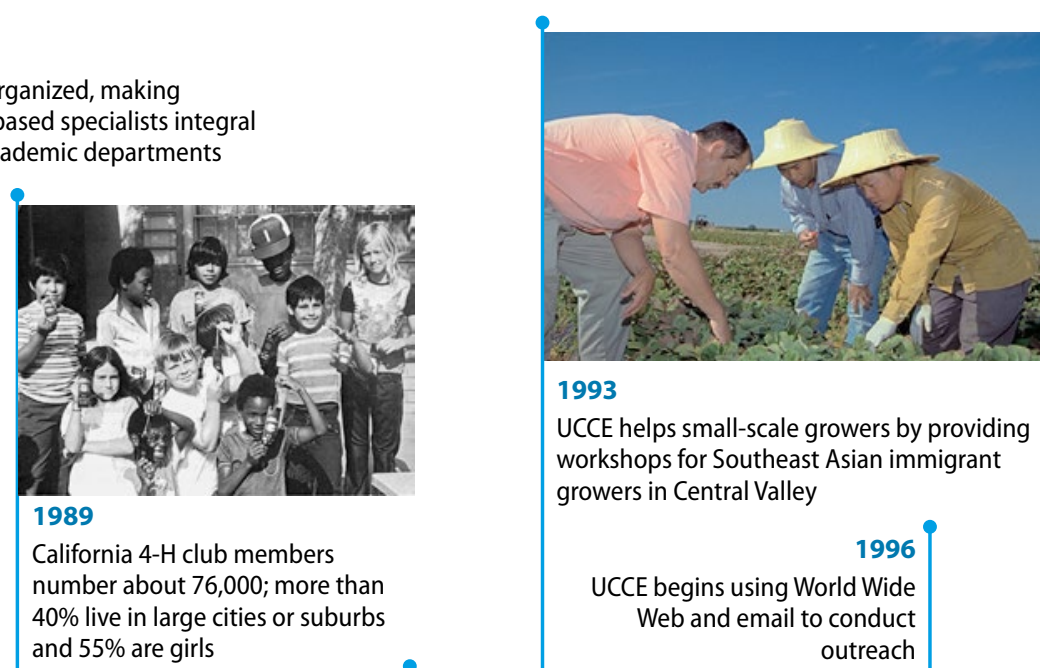
60 county offices throughout the state, and nine research and extension centers. It has

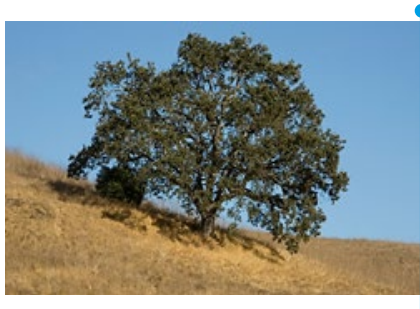

2001

UC scientists

1999

UCCE team documents significant benefits from agritourism to growers and communities in San Diego and other metropolitan counties

\section{develop integrated} approach to managing sudden oak death, a disease that has killed millions of oak trees growers in Central Valley

$$
\begin{array}{r}
1996 \\
\text { UCCE begins using World Wide } \\
\text { Web and email to conduct } \\
\text { outreach } \\
\text { Spanish-language UCCE specialist } \\
\text { begins using radio to teach } \\
\text { nutrition to Latino families }
\end{array}
$$

\section{Spanish-language UCCE specialist begins using radio to teach nutrition to Latino families}$$
1992
$$

Experts from UCCE analyze economic impact of sweet potato whitefly in Imperial Valley

\section{0}

1990

Money Talks program developed by UCCE home economists to help low-income families improve their financial situations

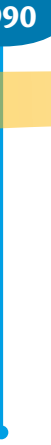

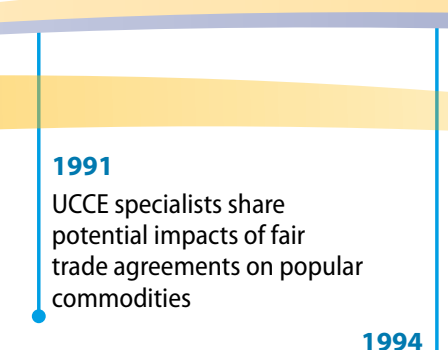

Study by UCCE scientists documents trend of growers using more sustainable farming practices

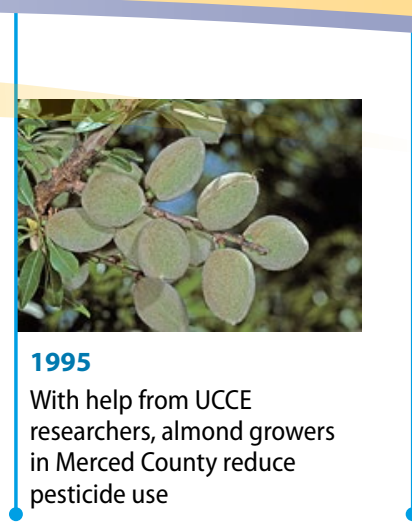

\section{0}


rural roots, but as the nation has grown and communities have changed, Cooperative Extension has evolved, adapting programs and developing new ones to meet the needs of rural and nonrural audiences. Since the 1960s, the Expanded Food and Nutrition Education Program (EFNEP) has provided free nutrition education classes in urban communities. Thousands of urban and suburban residents have benefited from the Master Gardener program, which offers workshops and advice to home, community and school gardeners; currently, more than 5,400 master gardener volunteers serve California communities. The Master Food Preserver program teaches Californians to safely preserve the healthy foods we produce. A new Master Naturalist program is training volunteers to help communities respond to complex issues in sustainable natural ecosystems; observations by volunteers in the community are recorded using mobile technologies so the data can be studied by scientists, who then respond to and help solve community problems.

All of Cooperative Extension's activities are grounded in university research and developed in partnership with local communities. After a century of service, UC Cooperative Extension continues to deliver practical, trusted, science-based solutions to Californians.

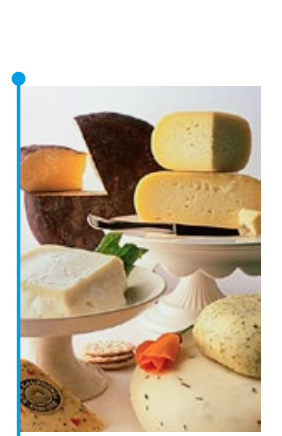

2005

Kearney Agricultural Research and

Extension Center celebrates 40 years

partnering with UCCE on research

2003

To help California cheesemakers develop successful marketing strategies, UCCE studies shopping habits of specialty cheese consumers

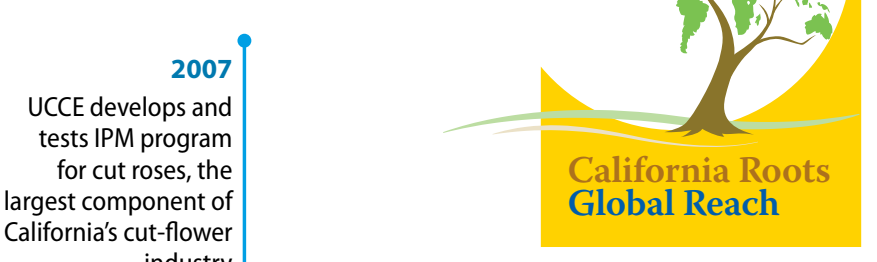

California's cut-flower industry

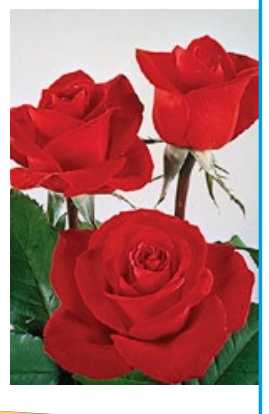
2010
Four UC ANR strategic initiatives established: Sustainable Food Systems, Healthy Families and Communities, Endemic and Invasive Pests and Diseases and Sustainable Natural Ecosystems
UCCE study finds Southern California nurseries adopting best practices for reducing water runoff from their facilities

2011

\section{Suggested reading}

Danbom D. 1979. The Resisted Revolution: Urban America and the Industrialization of Agriculture, 1900-1930. Ames, IA: Iowa State University Press.

Hayden-Smith R. 2012. Outlook: UC's land-grant mission fuels nation's growth, prosperity. Calif Agr 66(2):42-5. doi:10.3733/ca.v066n02p42.

Huffman WE, Evenson RE. 1993. Science for Agriculture. Ames, IA: Iowa State University Press.

Rasmussen WD. 1989. Taking the University to the People: Seventy-five Years of Cooperative Extension. Ames, IA: lowa State University Press.

Scheuring AF. 1995. Science and Service: A History of the Land-Grant University and Agriculture in California. Oakland, CA: UC ANR Publications.

Stage S, Vincente VB. 1997. Rethinking Home Economics: Women and the History of a Profession. Ithaca, NY: Cornell University Press.

Surls R, Hayden-Smith R. 2013. UC Cooperative Extension's collaborations grow with the centuries. Calif Agr 67(3):118. doi:10.3733/ca.v067n03p118.

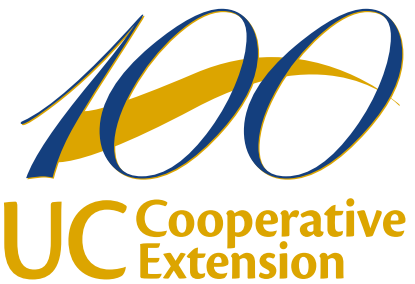

A Celebration of Science and Service

\begin{tabular}{r|l}
2013 & 2014 \\
UCCE celebrates \\
100 years of \\
bringing science \\
Global Food \\
and service \\
to California \\
comstems Forum, \\
committracting viewers \\
from more than \\
70 countries
\end{tabular}

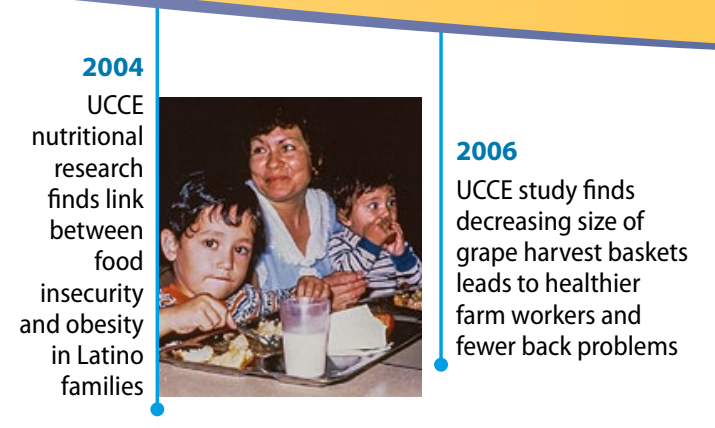

Strategic initiative for Water Quality, Quantity and Security established

Collaborative UCCE and UCD study on nitrate levels in groundwater released to State Water Board and governor

\begin{tabular}{l|l|l} 
& 2009 & \\
& $\begin{array}{l}\text { UC ANR introduces its Strategic } \\
\text { Vision through } 2025\end{array}$ & $\begin{array}{l}2012 \\
\text { UC ANR internal grants program } \\
\text { funds research and extension } \\
\text { education in new areas of } \\
\text { biofuels and local food systems } \\
\text { Sonoma and Napa UCCE study biocontrol }\end{array}$
\end{tabular}

in vineyards as part of CE's work on making viticulture more sustainable 